\title{
Pengaruh Pengawasan Langsung dan Tidak Langsung Terhadap Kinerja Pegawai Di Kantor Kementerian Agama Kabupaten Tasikmalaya
}

\author{
Astri Siti Fatimah \\ STIA YPPT PRIATIM Tasikmalaya \\ Email: astrifatimah@ymail.com
}

\begin{abstract}
This research aims to obtain data and information relating to the supervision and performance of employees. Research methods used in this research is descriptive research method of analysis. Then the data obtained processed and compiled up to gained clarity about the influence of the variable variable bound against free. Data collection techniques used through three ways: 1) observation (direct observation against the object of the research); 2) interviews; 3 question form); 4) study of the documentation. Based on a number of data research results and hypothesis test results by using path analysis (path analysis), it can be concluded that the direct and indirect supervision has a significant influence on performance of religious Ministry Office clerk in Tasikmalaya Regency. The magnitude of the influence on performance of such oversight specified direct and indirect supervision. The greatest contribution given by direct supervision then followed by indirect supervision.
\end{abstract}

Keywords: direct supervision, indirect supervision, performance

\begin{abstract}
Abstrak
Penelitian ini bertujuan untuk memperoleh data dan informasi yang berhubungan dengan pengawasan dan kinerja pegawai. Metode penelitian yang digunakan dalam penelitian ini adalah metode penelitian deskriptif analisis. Kemudian data yang diperoleh diolah dan disusun sampai diperoleh kejelasan tentang pengaruh variabel bebas terhadap variabel terikat. Teknik pengumpulan data yang digunakan melalui tiga cara yaitu : 1) observasi (pengamatan langsung terhadap obyek penelitian); 2) wawancara; 3) angket; 4) studi dokumentasi. Berdasarkan sejumlah data hasil penelitian dan hasil uji hipotesis dengan menggunakan analisis jalur (path analysis), dapat disimpulkan bahwa pengawasan langsung dan tidak langsung memiliki pengaruh yang signifikan terhadap kinerja pegawai di Kantor Kementerian Agama Kabupaten Tasikmalaya. Besarnya pengaruh pengawasan terhadap kinerja tersebut ditentukan pengawasan langsung dan tidak langsung. Kontribusi terbesar diberikan oleh pengawasan langsung kemudian berturut-turut diikuti oleh pengawasan tidak langsung.
\end{abstract}

Kata kunci : pengawasan langsung, pengawasan tidak langsung, kinerja 


\section{PENDAHULUAN}

Penelitian ini difokuskan dalam bidang agama. Yang dimaksud dengan urusan agama diantaranya menetapkan hari libur keagamaan yang berlaku secara nasional, memberikan pengakuan terhadap keberadaan suatu agama, menetapkan kebijakan dalam penyelenggaraan kehidupan keagamaan dan sebagainya: dan bagian tertentu urusan pemerintah lainnya yang berskala nasional, tidak diserahkan kepada daerah. Khusus di bidang keagamaan sebagian kegiatannya dapat ditugaskan oleh Pemerintah kepada Daerah sebagai upaya meningatkan keikutsertaan Daerah dalam menumbuh-kembangkan kehidupan beragama.

Penjelasan di atas menunjukkan bahwa urusan di bidang agama merupakan urusan pemerintah pusat yang selanjutnya disebut pemerintah secara adminintratif dalam konteks birokrasi kewenangannya dipegang oleh Kantor Kementerian Agama. Dalam implementasinya, di daerah-daerah terdapat institusi yang disebut Kantor Kementerian Agama, hingga di tingkat kabupaten/kota termasuk di Kabupaten Tasikmalaya.

Adapun kewenangan Kantor Kementerian Agama Kabupaten Tasikmalaya meliputi urusan Agama Islam, penerangan agama kepada masyarakat, majelis pendidikan Agama, pendidikan keagamaan dan pondok pesantren, urusan haji, penyelenggaraan zakat dan wakaf. Untuk mempermudah pelaksanaan pelayanan di bidang agama, secara administratif Kantor Kementerian Agama Kabupaten Tasikmalaya membentuk struktur organisatoris hingga tingkat kecamatan yang disebut Kantor Urusan Agama (KUA). Kedudukan Kantor Kementerian Agama beserta perangkat organisasi sebagai pamong merupakan organisasi pemerintah yang sangat vital, dimana organisasi ini secara langsung akan bersentuhan dengan permasalahan sosial masyarakat serta bidang pemerintahan, bidang pembangunan, bidang kemasyarakatan dan bidang-bidang lainnya.

Aspek pelayanan yang seharusnya diperankan oleh lembaga ini akhirnya menjadi berbalik. Justru menjadikan masyarakat yang harus melayani mereka (birokrat). Sebagai organisasi yang sangat dekat dengan lingkungan masyarakat, keberadaan organisasi lokal khususnya Kantor Kementerian Agama Kabupaten Tasikmalaya sangat ditentukan oleh penerimaan masyarakat. Oleh karena itu, dalam banyak hal lingkungan dari seorang pejabat lokal pada tingkat ini merupakan suatu daerah yang sarat dengan masalah. Pola-pola perilaku yang dikembangkan untuk melindungi dari tuntutan masyarakat antara lain berlindung di bawah peraturan atau mengisyaratkan bahwa apa yang ia kerjakan sudah merupakan instruksi dari pimpinan setempat. Kondisi obyektif di atas menunjukkan bahwa persoalan perilaku birokrat lokal tersebut merupakan persoalan umum yang ada dalam pemerintahan. Begitu pula persoalan spesifik yang terjadi khususnya pada Kantor Kementerian Agama Kabupaten Tasikmalaya sebagai obyek penelitian dalam penulisan ini.

Prawirosentono (1999) berpendapat bahwa dimensi-dimensi yang dijadikan ukuran kinerja antara lain adalah sebagai berikut :1. Efektivitas, 2. Otoritas dan tanggung jawab, 3. Disiplin, 4.Inisiatif. 
Sementara itu, Siagian (1995) mengemukakan bahwa teknik pengawasan terdiri dari dua macam yaitu : pertama pengawasan langsung (direct control), pengawasan langsung ini dapat berbentuk : a. inspeksi langsung, b. on - the-spot observation, c. on-the spot report. Sedangkan pengawasan yang kedua adalah pengawasan tidak langsung (indirect control), pengawasan ini dilakukan melalui laporan yang disampaikan oleh para bawahan. Laporan itu dapat berbentuk tertulis dan lisan.

Berdasarkan penelitian pendahuluan, diketahui bahwa kinerja pegawai di Kantor Kementerian Agama Kabupaten Tasikmalaya masih rendah. Indikator - indikator rendahnya kinerja pegawai sebagai berikut : pegawai kurang memiliki nilai kedisiplinan, keadilan dan tanggungjawab. Contoh : Masih adanya pegawai yang datang terlambat dan pulang sebelum waktunya bahkan di salah satu bagian ketika pegawai mendapat tugas dinas luar sering tidak kembali lagi ke kantor atau kalaupun kembali sudah menjelang apel siang/ jam kerja usai padahal tugas yang dilaksanakan tidak membutuhkan waktu yang lama dan tempat yang dituju tidak terlalu jauh dari kantor. Ada sebagian pegawai bekerja tidak sesuai dengan aturan yang ditetapkan. Contoh: Pada Bagian Tata Usaha Kepegawaian, penyelesaian mutasi pegawai KUA Kecamatan yang seharusnya diusulkan dari KUA/ Kecamatan melalui tata usaha kepegawaian, ternyata banyak yang mengusulkan dari Kepala Seksi. Rendahnya kinerja pegawai tersebut, diduga disebabkan karena lemahnya pengawasan oleh Kepala Kantor Kementerian Agama Kabupaten Tasikmalaya.

Atas dasar hal tersebut di atas, maka pertanyaan masalah (problem question) adalah : Seberapa besar pengaruh pengawasan langsung dan pengawasan tidak langsung terhadap kinerja pegawai di Kantor Kementerian Agama Kabupaten Tasikmalaya. Hipotesis penelitian ini adalah (1) Pengawasan langsung besar pengaruhnya terhadap kinerja pegawai di Kantor Kementerian Agama Kabupaten Tasikmalaya. (2) Pengawasan tidak langsung besar pengaruhnya terhadap kinerja pegawai di Kantor Kementerian Agama Kabupaten Tasikmalaya.

\section{METODE PENELITIAN}

Menurut Singarimbun dan Effendy (1995) penelitian eksplanatori (explanatory research) merupakan penelitian penjelasan yang menyoroti hubungan kausal antara variable-variabel penelitian dan menguji hipotesis yang telah dirumuskan sebelumnya.

Pada penelitian ini dirancang tentang bagaimana pengumpulan data akan dilakukan, kemudian analisis apa yang akan digunakan, serta bagaimana hasil analisis data harus diinterpretasikan, keseluruhan kegiatan tersebut akan dirinci berdasarkan kegiatan urutan penelitian yang akan dilakukan.

\section{HASIL DAN PEMBAHASAN}

Variabel penelitian ini terdiri dari dua variabel, yaitu variabel pengawasan sebagai variabel bebas yang diberi simbol $\mathrm{X}$ dan variabel kinerja pegawai sebagai variabel terikat yang diberi simbol $\mathrm{Y}$. Penelitian ini dilakukan dengan cara menganalisis variabel pengawasan yang diperkirakan 
mempunyai pengaruh besar terhadap kinerja pegawai, rangkaian penelitian yang dilakukan sebagia suatu studi di Kantor Kementerian Agama Kabupaten Tasikmalaya.

Pada penelitian ini yang dijadikan sebagai unit analisis adalah para pegawai yang ada di lingkungan kerja Kantor Kementerian Agama Kabupaten Tasikmalaya yang berjumlah 63 orang. Selanjutnya kepada responden tersebut diajukan pertanyaan-pertanyaan dalam angket yang merupakan penjabaran dari indikator-indikator variabel pengawasan dan variabel kinerja pegawai.

Indikator-indikator dalam setiap variabel penelitian dituangkan ke dalam pernyataan tertutup, dimana setiap pernyataan angket memiliki lima alternatif jawaban yang dapat dipilih oleh responden. Alternatif tersebut diberi skor dari 5 sampai 1 untuk pernyataan yang positif dan skor 1 sampai 5 untuk pernyataan yang negatif. Sebelum melakukan analisis data secara komprehensif, terlebih dahulu dilakukan pengujian terhadap instrumen penelitian yaitu melalui pengujian validitas dan reliabilitas terhadap instrumen penelitian.

Instrumen penelitian diuji dengan tujuan untuk mengetahui apakah insturmen telah memenuhi persyaratan ditinjau dari segi kesahihan/validitas maupun dari segi keterandalan/reliabilitasnya. Sebuah instrumen penelitian dapat dikatakan valid jika insturmen penelitian tersebut dapat digunakan untuk mengukur apa yang seharusnya diukur. Dengan demikian, sebuah instrumen dapat dikatakan sahih apabila dapat mengukur apa yang diukur. Instrumen dikatakan valid apabila mampu mengukur apa yang diinginkan. Tinggi rendahnya validitas instrumen menunjukkan sejauh mana data yang terkumpul tidak menyimpang dari gambaran tentang variabel yang dimaksud.

Adapun alat pengujian yang dipakai adalah korelasi Product Moment dari Karl Pearson sebagaimana yang dikutip oleh Arikunto (1998) sebagai berikut :

Tabel 1

Hasil Perhitungan Uji Validitas Sub Variabel $\mathbf{X}_{1}$ (Pengawasan Langsung)

\begin{tabular}{|c|c|c|}
\hline $\begin{array}{c}\text { No. Butir } \\
\text { Instrumen }\end{array}$ & r hitung & Keterangan \\
\hline 1 & 0,362 & Valid \\
\hline 2 & 0,407 & Valid \\
\hline 3 & 0,403 & Valid \\
\hline 4 & 0,335 & Valid \\
\hline 5 & 0,351 & Valid \\
\hline 6 & 0,490 & Valid \\
\hline 7 & 0,337 & Valid \\
\hline 8 & 0,269 & Valid \\
\hline 9 & 0,440 & Valid \\
\hline 10 & 0,394 & Valid \\
\hline
\end{tabular}




\begin{tabular}{|c|c|c|}
\hline 11 & 0,289 & Valid \\
\hline
\end{tabular}

Sumber : Hasil Pengolahan Data, Tahun 2015

Tabel 2

\section{Hasil Perhitungan Uji Validitas Sub Variabel $\mathbf{X}_{2}$} (Pengawasan Tidak Langsung)

\begin{tabular}{|c|c|c|}
\hline $\begin{array}{c}\text { No. Butir } \\
\text { Instrumen }\end{array}$ & r hitung & Keterangan \\
\hline 12 & 0,262 & Valid \\
\hline 13 & 0,453 & Valid \\
\hline 14 & 0,258 & Valid \\
\hline 15 & 0,277 & Valid \\
\hline 16 & 0,458 & Valid \\
\hline 17 & 0,398 & Valid \\
\hline 18 & 0,356 & Valid \\
\hline 19 & 0,285 & Valid \\
\hline 20 & 0,294 & Valid \\
\hline 21 & 0,351 & Valid \\
\hline 22 & 0,314 & Valid \\
\hline 23 & 0,309 & Valid \\
\hline
\end{tabular}

Sumber : Hasil Pengolahan Data, Tahun 2015

Hasil uji validitas variabel kinerja pegawai (Y) ditunjukkan dalam tabel di bawah ini :

Tabel 3

Hasil Perhitungan Uji Validitas Variabel Y

(Kinerja Pegawai)

\begin{tabular}{|c|c|c|}
\hline $\begin{array}{c}\text { No. Butir } \\
\text { Instrumen }\end{array}$ & r hitung & Keterangan \\
\hline 24 & 0,373 & Valid \\
\hline 25 & 0,396 & Valid \\
\hline 26 & 0,404 & Valid \\
\hline 27 & 0,294 & Valid \\
\hline 28 & 0,385 & Valid \\
\hline 29 & 0,390 & Valid \\
\hline 30 & 0,286 & Valid \\
\hline 31 & 0,469 & Valid \\
\hline 32 & 0,391 & Valid \\
\hline
\end{tabular}




\begin{tabular}{|l|l|l|}
\hline 33 & 0,385 & Valid \\
\hline 34 & 0,450 & Valid \\
\hline 35 & 0,462 & Valid \\
\hline 36 & 0,246 & Valid \\
\hline 37 & 0,336 & Valid \\
\hline 38 & 0,334 & Valid \\
\hline 39 & 0,367 & Valid \\
\hline 40 & 0,294 & Valid \\
\hline 41 & 0,387 & Valid \\
\hline
\end{tabular}

Sumber : Hasil Pengolahan Data, Tahun 2015

Suatu item dikatakan valid apabila nilai $\mathrm{r}$ atau nilai korelasi antara skor item dengan skor totalnya menunjukkan koefisien yang signifikan, dikatakan signifikan apabila nilai $\mathbf{r}_{\text {tabel }}$ dari item lebih kecil dari nilai $r_{\text {hitung. Nilai }} \mathrm{r}_{\text {tabel }}$ mengacu pada tabel $\mathrm{r}$ untuk korelasi product moment dan ditentukan besarnya $\alpha=0,05$ dan $n=63$. Berdasarkan perhitungan tersbeut diperoleh nilai $\mathrm{r}_{\text {tabel }}=$ 0,244, apabila terdapat item pernyataan yang tidak valid, maka data yang didapat tidak bisa digunakan untuk analisis selanjutnya.

Reliabilitas menunjukkan pada pengertian bahwa sesuatu instrumen cukup dipercaya digunakan sebagai alat pengumpul data karena isntrumen tersebut sudah baik. Instrumen yang baik tidak akan bersifat tendesius mengarahkan respondne untuk memilih jawaban-jawaban tertentu.

Menurut Arikunto (1998 : 170), "Reliabilitas menunjuk pada tingkat keterandalan sesuatu. Artinya, terpercaya atau dapat dipercaya oleh karena itu dapat diandalkan". Instrumen yang reliabel akan menghasilkan data yang dapat dipercaya. Untuk mengukur reliabilitas kuesioner dalam penelitian ini digunakan metode Alpha Cronbach dengan rumus sebagai berikut :

Tabel 4

Hasil Uji Reliabilitas Variabel X dan Y

\begin{tabular}{|l|c|}
\hline \multicolumn{1}{|c|}{ Variabel Penelitian } & $\begin{array}{c}\text { Hasil Uji } \\
\text { Alpha } \\
\text { Cronbach }\end{array}$ \\
\hline Pengawasan (X) & 0,678 \\
\hline Kinerja Pegawai (Y) & 0,624 \\
\hline
\end{tabular}

Sumber : Hasil Pengolahan Data, Tahun 2010

Berdasarkan hasil perhitungan Alpha Cronbach tersebut di atas, maka kedua variabel dinyatakan reliabel. Hal ini didasarkan pada ketentuan dimana hasil hitung kedua variabel tersebut 
melebihi batas minimum 0,60. Sedangkan menurut Balian dalam Arikunto (1998) koefisien reliabilitas berada pada posisi 0,70 - 0,79 dikatakan fair (reliabel).

Berdasarkan rumusan hipotesis yang menyatakan : "Pengawasan langsung besar pengaruhnya terhadap kinerja pegawai di Kantor Kementerian Agama Kabupaten Tasikmalaya.”, maka untuk menguji adanya pengaruh pengawasan langsung terhadap kinerja pegawai dapat dirumuskan hipotesis statistik sebagai berikut :

$\mathrm{H}_{0}: \mathrm{Pyx}_{1}=0 \rightarrow$ Tidak ada pengaruh pengawasan langsung terhadap kinerja pegawai

$\mathrm{H}_{1}: \operatorname{Pyx}_{1} \neq 0 \rightarrow$ Ada pengaruh pengawasan langsung terhadap kinerja pegawai

Uji hipotesis ini dilakukan dengan cara pengujian koefisien jalur pada out put persamaan regresi, dimana berdasarkan hasil pengujian diperoleh koefisien jalur sebesar 0,5222.

Untuk mengetahui lebih lanjut pengaruh $\mathrm{X}_{1}$ terhadap $\mathrm{Y}$, maka dilakukan pengujian, yaitu dengan melihat perbandingan antara thitung dengan $t_{\text {tabel. }}$. Berdasarkan pengujian diperoleh nilai thitung lebih besar dari nilai $\mathrm{t}_{\text {tabel }}\left(\mathrm{t}_{0,975 ; 63)}\right.$ yaitu $\mathrm{t}_{\text {hitung }}=5,784>\mathrm{t}_{\text {tabel }}=2,000$. Dari nilai tersebut diperoleh keputusan $\mathrm{H}_{0}$ ditolak dan $\mathrm{H}_{1}$ diterima, hal ini berarti bahwa sub variabel pengawasan langsung $\left(\mathrm{X}_{1}\right)$ berpengaruh secara signifikan terhadap variabel kinerja pegawai $(\mathrm{Y})$.

Koefisien determinasi $\left(\mathrm{R}^{2}{ }_{\mathrm{YX} 1}\right)$ sebesar 0,2726 , ini menunjukkan bahwa pegawasan langsung $\left(\mathrm{X}_{1}\right)$ berpengaruh terhadap kinerja pegawai $(\mathrm{Y})$ sebesar $27,26 \%$, sedangkan sisanya sebesar $72,74 \%$ dipengaruhi oleh sub variabel pengawasan tidak langsung dan banyak variabel lain yang tidak dimasukan ke dalam model regresi (variabel yang tidak diteliti).

Efek dari sub variabel pengawasan langsung $\left(\mathrm{X}_{1}\right)$ terhadap kinerja pegawai, berdasarkan hasil pengujian diperoleh efek langsung sebesar $27,26 \%$. Sedangkan efek tidak langsung sub variabel pengawasan langsung melalui sub variabel pengawasan tidak langsung $\left(\mathrm{X}_{2}\right)$ sebesar $10,26 \%$, Dengan demikian total efek sub variabel pengawasan langsung $\left(\mathrm{X}_{1}\right)$ terhadap variabel kinerja pegawai (Y) baik langsung maupun tidak langsung sebesar 37,52\%.

Berdasarkan pengujian hipotesis tersebut dapat diperoleh gambaran bahwa pengawasan langsung berpengaruh terhadap kinerja pegawai sebesar 37,52\%. Hal ini berarti bahwa kinerja pegawai tidak hanya dipengaruhi oleh pengawasan langsung saja, akan tetapi dipengaruhi pula oleh pengawasan tidak langsung serta banyak variabel lainnya yaitu sebesar $62,48 \%$.

Hal ini menunjukkan bahwa masih banyak variabel-variabel lain yang memiliki kontribusi terhadap peningkatan kinerja pegawai, seperti yang dikemukakan Notoatmojo (1992) yang menyatakan bahwa selain melihat faktor-faktor yang mempengaruhi kinerja, juga harus memperhatikan beberapa hal, antara lain : penilaian yang dilakukan harus mempunyai hubungan dengan pekerjaan (job related), adanya standar pelaksanaan kerja, praktis, yaitu mudah dipahami dan dikerjakan baik oleh penilai maupun yang dinilai dan objektivitas penilaian. Keempat hal tersebut merupakan variabel-variabel tidak langsung yang memiliki kontribusi terhadap kinerja pegawai.

Pengaruh Pengawasan Tidak Langsung terhadap Kinerja Pegawai di Kantor Kementerian Agama Kabupaten Tasikmalaya sebagai berikut: 
Berdasarkan rumusan hipotesis yang menyatakan : "Pengawasan tidak langsung besar pengaruhnya terhadap kinerja pegawai di Kantor Kementerian Agama Kabupaten Tasikmalaya.", maka untuk menguji adanya pengaruh pengawasan tidak langsung terhadap kinerja pegawai dapat dirumuskan hipotesis statistik sebagai berikut :

$\mathrm{H}_{0}: \mathrm{Pyx}_{1}=0 \rightarrow$ Tidak ada pengaruh pengawasan tidak langsung terhadap kinerja pegawai $\mathrm{H}_{1}: \mathrm{Pyx}_{1} \neq 0 \rightarrow$ Ada pengaruh pengawasan tidak langsung terhadap kinerja pegawai Uji hipotesis ini dilakukan dengan cara pengujian koefisien jalur pada out put persamaan regresi, dimana berdasarkan hasil pengujian diperoleh koefisien jalur sebesar 0,3937.

Untuk mengetahui lebih lanjut pengaruh $\mathrm{X}_{2}$ terhadap $\mathrm{Y}$, maka dilakukan pengujian, yaitu dengan melihat perbandingan antara thitung dengan tabel. Berdasarkan pengujian diperoleh nilai thitung lebih besar dari nilai $\mathrm{t}_{\text {tabel }}\left(\mathrm{t}_{0,975 ; 63)}\right.$ yaitu thitung $=4,361>\mathrm{t}_{\text {tabel }}=2,000$. Dari nilai tersebut diperoleh keputusan $\mathrm{H}_{0}$ ditolak dan $\mathrm{H}_{1}$ diterima, hal ini berarti bahwa sub variabel pengawasan tidak langsung $\left(\mathrm{X}_{2}\right)$ berpengaruh secara signifikan terhadap variabel kinerja pegawai $(\mathrm{Y})$.

Koefisien determinasi $\left(\mathrm{R}^{2} \mathrm{YX} 2\right)$ sebesar 0,1550 , ini menunjukkan bahwa pegawasan tidak langsung $\left(\mathrm{X}_{2}\right)$ berpengaruh terhadap kinerja pegawai $(\mathrm{Y})$ sebesar $15,50 \%$, sedangkan sisanya sebesar $84,50 \%$ dipengaruhi oleh sub variabel pengawasan langsung dan banyak variabel lain yang tidak dimasukan ke dalam model regresi (variabel yang tidak diteliti).

Efek dari sub variabel pengawasan tidak langsung $\left(\mathrm{X}_{2}\right)$ terhadap kinerja pegawai, berdasarkan hasil pengujian diperoleh efek langsung sebesar 15,50\%. Sedangkan efek tidak langsung sub variabel pengawasan langsung melalui sub variabel pengawasan langsung $\left(\mathrm{X}_{1}\right)$ sebesar 10,26\%, Dengan demikian total efek sub variabel pengawasan tidak langsung $\left(\mathrm{X}_{2}\right)$ terhadap variabel kinerja pegawai $(\mathrm{Y})$ baik efek langsung maupun efek tidak langsung sebesar 25,76\%.

Berdasarkan pengujian hipotesis tersebut dapat diperoleh gambaran bahwa pengawasan tidak langsung berpengaruh terhadap kinerja pegawai sebesar $25,76 \%$. Hal ini berarti bahwa kinerja pegawai tidak hanya dipengaruhi oleh pengawasan tidak langsung saja, akan tetapi dipengaruhi pula oleh pengawasan langsung serta banyak variabel lainnya yaitu sebesar 74,24\%.

Adapun variabel lain yang memiliki kontribusi terhadap kinerja pegawai menurut Notoatmojo (1992) antara lain : ability (kemampuan pembawaan), capacity (kemampuan yang dapat dikembangkan), help (bantuan untuk terwujudnya performance), Incentive (insentif material maupun non material), environment (lingkungan tempat kerja karyawan) dan evalution (adanya umpan balik hasil kerja). Hal ini menunjukkan bahwa masih banyak variabel-varibel lain selain variabel yang di teliti yang penting untuk diperhatikan guna meningkatkan kinerja pegawai.

Pengaruh Langsung dan Tidak Langsung terhadap Kinerja Pegawai di Kantor Kementerian Agama Kabupaten Tasikmalaya, sebagai berikut :

Bertolak pada rumusan hipotesis yang menyatakan : "Pengawasan langsung dan pengawasan tidak langsung besar pengaruhnya terhadap kinerja pegawai di Kantor Kementerian Agama Kabupaten Tasikmalaya", maka untuk menguji adanya pengaruh pengawasan (yang meliputi : pengawasan langsung dan pengawasan tidak langsung) terhadap kinerja pegawai dapat dirumuskan hipotesis statistik sebagai berikut : 
$\mathrm{H}_{0}: \mathrm{Pyx}=0 \rightarrow$ Tidak ada pengaruh pengawasan (yang meliputi : pengawasan langsung dan pengawasan tidak langsung) terhadap kinerja pegawai

$\mathrm{H}_{1}: \mathrm{Pyx} \neq 0 \rightarrow$ Ada pengaruh pengawasan (yang meliputi : pengawasan langsung dan pengawasan tidak langsung) terhadap kinerja pegawai

Dengan demikian maka untuk menguji hipotesis yang diajukan tersebut, dilakukan analisis model summary pada out put persamaan regresi, dimana berdasarkan hasil pengujian diperoleh koefisien korelasi ganda sebesar $0,79548688 \approx 0,795$.

Guna mengetahui lebih lanjut pengaruh simultan $\mathrm{X}_{1}$ dan $\mathrm{X}_{2}$ terhadap $\mathrm{Y}$, maka dilakukan pengujian, yaitu dengan melihat perbandingan antara $\mathrm{F}_{\text {hitung }}$ dengan $\mathrm{F}_{\text {tabel. }}$. Berdasarkan pengujian diperoleh nilai $F_{\text {hitung }}$ lebih besar dari nilai $F_{\text {tabel }}\left(t_{0,975 ; 2 ; 60)}\right.$ yaitu $F_{\text {hitung }}=38,996>F_{\text {tabel }}=3,150$. Dari nilai tersebut diperoleh keputusan $\mathrm{H}_{0}$ ditolak dan $\mathrm{H}_{1}$ diterima, hal ini berarti bahwa variabel pengawasan (yang meliputi : pengawasan langsung dan pengawasan tidak langsung) berpengaruh secara signifikan terhadap variabel kinerja pegawai $(\mathrm{Y})$.

Koefisien determinasi $\left(\mathrm{R}^{2} \mathrm{YX1X2X3 \times 4}\right)$ sebesar 0,63279937, menunjukkan bahwa pengawasan (yang meliputi : pengawasan langsung dan pengawasan tidak langsung) berpengaruh terhadap kinerja pegawai (Y) sebesar 63,28\%, sedangkan sisanya sebesar 36,72\% dipengaruhi oleh banyak variabel lain yang tidak dimasukan ke dalam model regresi (variabel yang tidak diteliti).

Berdasarkan pengujian hipotesis tersebut dapat diperoleh gambaran bahwa pengawasan (yang meliputi : pengawasan langsung dan pengawasan tidak langsung) berpengaruh terhadap kinerja pegawai sebesar $63,28 \%$. Hal ini berarti bahwa kinerja pegawai tidak hanya dipengaruhi oleh variabel pengawasan (yang meliputi : pengawasan langsung dan pengawasan tidak langsung) saja, akan tetapi dipengaruhi pula oleh banyak variabel lainnya yaitu sebesar 36,72\%. Untuk lebih jelasnya dapat penulis jelaskan dalam bentuk gambar hasil penelitian sebagai berikut :

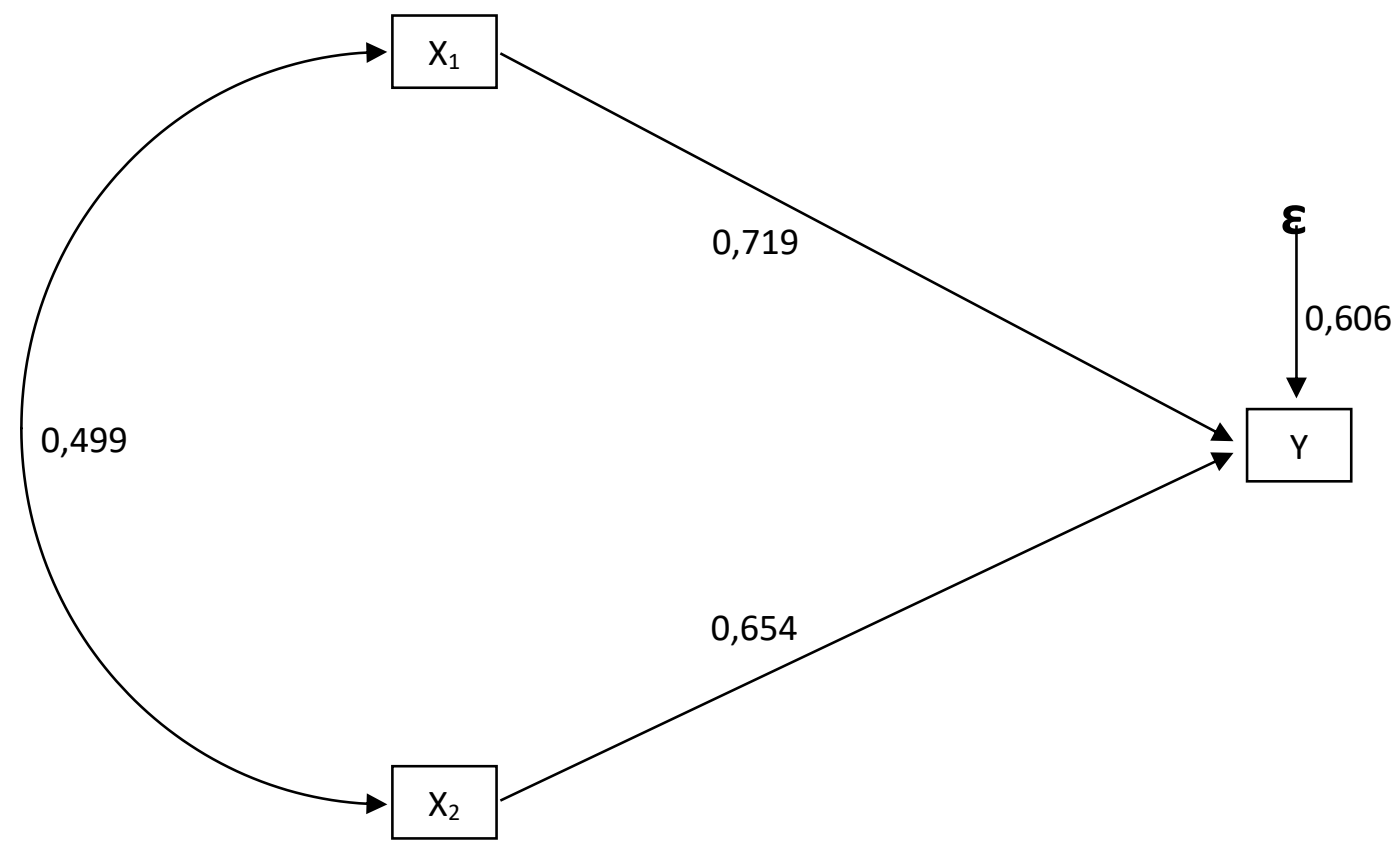




\begin{tabular}{|l|l|l|}
\hline Pengaruh $\mathrm{X}_{1}$ terhadap $\mathrm{Y}$ & & \\
\hline 1. Pengaruh langsung & 0,2726 & \\
\hline 2. Pengaruh tak langsung melalui $\mathrm{X}_{2}$ & 0,1026 & \\
\hline Total pengaruh $\mathrm{X}_{1}$ terhadap $\mathrm{Y}$ & & 0,3752 \\
\hline & & \\
\hline & & \\
\hline Pengaruh $\mathrm{X}_{2}$ terhadap $\mathrm{Y}$ & 0,1550 & \\
\hline 1. Pengaruh langsung & 0,1026 & \\
\hline 2. Pengaruh tak langsung melalui $\mathrm{X}_{1}$ & & 0,2576 \\
\hline Total pengaruh $\mathrm{X}_{2}$ terhadap $\mathrm{Y}$ & & \\
\hline & & \\
\hline & & $\mathbf{0 , 6 3 2 8}$ \\
\hline Total pengaruh $\mathrm{X}$ terhadap $\mathrm{Y}$ & & $\mathbf{0 , 3 6 7 2}$ \\
\hline Pengaruh variabel lain $(\boldsymbol{\varepsilon})$ & & \\
\hline
\end{tabular}

Berdasarkan hasil penelitian dan pembahasan, dapat disimpulkan hasil analisis sebagai berikut :

1. Pengawasan secara empirik telah terbukti memberikan pengaruh yang signifikan terhadap kinerja pegawai di Kantor Kementerian Agama Kabupaten Tasikmalaya, baik secara parsial maupun secara simultan. Besarnya pengaruh pengawasan terhadap kinerja pegawai di Kantor Kementerian Agama Kabupaten Tasikmalaya tercermin dari besarnya pengaruh dimensidimensi pengawasan yang secara teoritik terdiri dari dimensi pengawasan langsung dan pengawasan tidak langsung.

2. Hasil penelitian juga menunjukkan bahwa dimensi pengaruh langsung secara empirik telah memberikan pengaruh lebih besar terhadap kinerja pegawai di Departemen Agama Kabupaten Tasikmalaya yang tercermin dari indikator pimpinan melihat langsung kerja bawahan, pimpinan menegur bawahan yang bekerja tidak sesuai dengan rencana, pimpinan menegur bawahan yang tidak mematuhi aturan kerja dan pimpinan melakukan koreksi hasil kerja bawahan di tempat kerjanya. Sedangkan dimensi pengawasan tidak langsung merupakan dimensi yang lebih kecil memberikan pengaruh terhadap kinerja pegawai.

3. Hasil temuan penelitian juga mendapatkan fakta bahwa kinerja pegawai ternyata tidak hanya dipengaruhi oleh pengawasan saja, akan tetapi juga dipengaruhi oleh banyak faktor lain. Adapun faktor lain yang dimaksud, tiga diantaranya adalah faktor motivasi, kepemimpinan dan belum optimalnya pengorganisasian yang dilakukan.

\section{KESIMPULAN}

Berdasarkan uraian di atas, maka dapat dikemukakan bahwa pengawasan langsung yang dilakukan oleh atasan kepada bawahan harus lebih intensif lagi terutama dalam hal pimpinan melihat langsung kerja bawahan. Dengan hanya melihat langsung seorang pimpinan terhadap kerja bawahannya saja tidak akan mampu menyelesaikan permasalahan ketidakdisiplinan pegawai, 
maka pengawasan dalam bentuk melihat langsung kerja bawahan harus diiringi dengan sikap tegas pimpinan untuk memberikan sanksi bagi bawahan yang bekerja tidak sesuai aturan.

Perlu adanya penekanan dari pimpinan, terutama terkait dengan penyusunan laporan hasil kerja yang harus selesai tepat waktu, sehingga bawahan akan terpacu untuk bekerja lebih giat yang pada gilirannya akan meningkatkan inisiatif pegawai yang bersangkutan dalam melaksanakan tugas-tugasnya.

Pengawasan tidak langsung dalam wujud pimpinan memanggil bawahan yang lalai dalam melaksanakan pekerjaan, harus lebih ditingkatkan lagi. Hal ini dilakukan untuk meminimalisir kinerja bawahan yang tidak sesuai dengan aturan kerja yang seharusnya, dimana jika hal ini dibiarkan berlarut-larut maka akan dapat menurunkan tingkat kinerja pegawai ke arah yang kurang baik. Namun begitu, untuk lebih meningkatkan tingkat kinerja pegawai ke arah yang lebih baik selain memanggil bawahan yang lalai dalam melaksanakan pekerjaan untuk diberi peringatan atau arahan-arahan, diperlukan juga bentuk pengawasan langsung berupa pimpinan mengawasi kegiatan pegawai dalam melaksanakan tugas-tugasnya dan pimpinan pun harus melakukan penilaian terhadap hasil-hasil pelaksanaan tugas bawahannya. 


\section{DAFTAR PUSTAKA}

Aditama. (2003). Manajemen Pola Kerja Terpadu, Jakarta : LAN RI.

Atmosudirdjo, Prajudi. (1982). Administrasi dan Manajemen, Jakarta : Ghalia Indonesia.

Dwiyanto, Agus. (2002). Penilaian Kinerja Organisasi Pelayanan Publik, Yogyakarta : FISIP UGM.

Hidayat. (1998). Konsep Dasar dan Pengertian Produktivitas serta Interpretasi Hasil Pengukurannya, Prisma: Nomor 11.

Jackson, Mathis. (2001). Rekayasa Ulang Proses Bisnis : Strategi Terobosan Untuk Dominasi Pasar, Alih Bahasa Maulana, Jakarta : Binarupa.

Notoatmojo. (1992). Akuntabilitas Kinerja Pemerintah, Jakarta : LAN RI.

Prawirosentono. (1999). Organisasi Perusahaan, Jakarta : Karunia.

Siagian. (1995). Organisasi, Kepemimpinan dan Perilaku Organisasi, Jakarta : Gunung Agung.

Silalahi, Ulbert. (2003). Studi Tentang Ilmu Administrasi, Bandung : Sinar.

Sugiyono. (2003). Metode Penelitian Administrasi, Bandung : Alphabeta.

Sulistiyani. (2003). Peningkatan Produktivitas, Strategi dan Upaya Perencanaannya, Jakarta : Karunia. 